International Journal of Instruction

e-ISSN: 1308-1470 • www.e-iji.net

Article submission code:

20200512113740

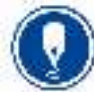

Received: $12 / 05 / 2020$

Revision: 24/12/2020
July $2021 \bullet$ Vol.14, No.3

p-ISSN: 1694-609X

pp. 417-432

Accepted: 19/01/2021

OnlineFirst: 22/05/2021

\title{
The Effect of Digital Learning Material on Students' Social Skills in Social Studies Learning
}

\section{Sariyatun}

Prof., History Education Department, Sebelas Maret University, Surakarta, Indonesia, sariyatun@staff.uns.ac.id

\section{Nunuk Suryani}

Prof., History Education Department, Sebelas Maret University, Surakarta, Indonesia, nunuksuryani@staff.uns.ac.id

\section{Leo Agung Sutimin}

Prof., History Education Department, Sebelas Maret University, Surakarta, Indonesia, leoagung@staff.uns.ac.id

\section{Nur Fatah Abidin}

Lecturer, History Education Department, Sebelas Maret University, Surakarta, Indonesia,nurfatah@staff.uns.ac.id

\section{Atqo Akmal}

Postgraduate Program, History Education Department, Sebelas Maret University, Surakarta, Indonesia,atqoakmal@gmail.com

This research analyses the effect of digital learning material on students' social skills in social studies learning. Quantitative comparative was used as the method to compare the effectiveness of digital learning material and printed-out textbooks in improving students' social skills. The research participants were 80 junior high school students, which consisted of 40 students in the experimental group and 40 students in the control group. Students in the experimental group learnt social studies by using digital learning material, meanwhile, students in the control group used printed-out textbooks. The result of the research shows the difference between control group and experimental group, which is proven by the result of the independent sample t-test 0.028. It means that the experimental group, which uses digital learning material, has a greater average of students' social skills rather than the control group. This proves that digital learning material is more effective in improving students' social skills rather than the printed-out textbooks.

Keywords: digital learning material, social studies learning, social skills, students' social skills, learning

Citation: Sariyatun., Suryani, N., Sutimin, L. A., Abidin, N. F., \& Akmal, A. (2021). The Effect of Digital Learning Material on Students' Social Skills in Social Studies Learning. International Journal of Instruction, 14(3), 417-432. https://doi.org/10.29333/iji.2021.14324a 


\section{INTRODUCTION}

One of the main objectives of social studies learning is to construct students' social skills (Legare, Opfer, Busch, and Shtulman, 2018; Elliott, Malecki, and Demaray, 2004). Social skills is broadly defined as social intelligence of a person that becomes the basic foundation to do social relations in society (Thorndike and Stein, 1937). Social skills take an important role in the process of production or reproduction of social norms as well as social order (Fligstein, 2001). Several aspects can be categorized as social skills such as social tasks (Gresham and Elliott, 1984), social cooperation (Johnson and Johnson, 1989), and social communication (Riggio and Reichard, 2008). Social skills is also considered as the basic of reasoning skills, critical thinking, and logical thinking (García-Álvarez, Novo-Corti, Varela Candamio, 2018). To be low on social skills can trigger negative effects for students, especially on their social adaptation in society (Chou et al., 2017).

Learning material plays an important role in constructing social skills in social studies learning. Learning material can be defined as a set of materials consisting of theory and praxis of social skills, descriptions of sociological theory, and also information about sociological problems. Substantively, learning material consists of information and data about social controversial issues that can be used in the learning activities of students in the form of written texts (Kaviani, 2006). Moreover, learning material also contains social knowledge and social discourse in which students learn social norms and social order through written exemplary cases or the best practices (Zulkifli, 2019). Learning material also consists of students' tasks to train students' contextual analysis in solving a social problem (Saglam, 2011). Learning material is interconnected to curriculum and textbooks that determines the learning process in the classroom (Batra, 2008). Students' task in the learning material aims to extend students' understanding of theory or concepts that had been learned from the textbooks (Singer, 2008).

Researchers have predicted that the future of social studies learning is digital. The symptom of digitalization can be seen in the learning process when teachers use digital learning material. Digital learning materials can be defined as the digitized and interconnected learning materials. According to Asiry's (2017) research, the tendency to use digital learning material comes from teachers' and students' acceptance of technology in the learning process. Moreover, Sariyatun, Joebagio, and Akhyar (2018) emphasizes teachers' practical reasons in using digital learning material such as teachers' assumption of digital learning materials can be more interesting, easier to understand, and less expensive for students. However, some of the researchers as well as teachers argue about the effectiveness of digital learning material in supporting students' learning activities. Acker, Buuren, Kreijas, and Vermeulen (2013) state that teachers tend to believe that digital learning material is unfruitful for social studies learning. They mention several determinant factors of teachers' motivation in using digital learning material encompassing self-efficacy, subjective norm, and attitude. Teachers and students also perceive that social studies learning needs social interaction and communication rather than technological assistance. 
Based on the above descriptions, it can be marked that the use of digital learning in social studies learning is still problematic. The main question is about the effectiveness of digital learning material in improving students' social skills in comparison with the conventional learning materials, such as the printed-out textbook that is commonly used in the learning process. This question came from the impact of digital learning material, which mostly operates in digital form and online, in nurturing students' social skills, which needs intensive social interaction and communication. This research aims to examine the effects of digital learning material on students' social skills through experimental research. The authors try to compare the use of digital learning material and the existing printed-out textbooks in the social studies learning process. The authors assume that the use of digital learning material can give a greater impact on the improvement of students' social skills. This experiment becomes important to give a better understanding on the effect of digital learning material to improve students' social skills. If digital learning material can give more benefits to the improvement of students' social skills, then the digitalization of learning should be considered for the future of social studies learning.

\section{Literature Review}

\section{Social Skills}

Thorndike and Stein's classical work become the foundation of the theoretical framework of social skills. Thorndike and Stein explain that social skills have a correlation with social intelligence that are needed for social interaction (Thorndike and Stein, 1937). According to Gresham and Elliott (1984), social skills consist of specific behaviors of an individual to perform social tasks. These also represent the individual ability to interact with other people appropriately. Gresham and Elliott (2010) then explain that social tasks might be in the form of peer group acceptance, initiating and sustaining conversation, playing a game with peers, or getting new friends.

According to Riggio and Reichard (2008), social skills can be categorized as one of the constructions of interpersonal communication skills. Riggio and Reichard state that skill to communicate including oral communication or speaking skills. Moreover, they also explain that interpersonal communication is related to emotional and social skills including three basic skills, namely expressing emotion or feeling; identifying, translating, and decoding messages from others; and managing communication behaviors. Besides that, personal ability to cooperate with others also can be considered as social skills. Johnson and Johnson (1989) examine that cooperative action in the learning activity can help students to improve the quality of their relationship with classmates and give a positive influence on their psychological health. Thus, it can be highlighted that interpersonal communication becomes one of the main aspects of social skills. Hutching (2019) categorizes social skills as part of social competence. Social competence can be seen as the synthesis of interactional skills and social attitudes that enable an individual to take social performance in any social context. Hutching adds that the core of social skills is the ability of a person to establish communication. Social competence can be built by observing and imitating other people. Practices, demonstrations and feedback also can build social skills. 
Based on the above theoretical discussion, it can be highlighted that social skills become the foundation of social relationships. Social skills can be defined as the ability of the person to do interpersonal communication with other people in society. Social skills can be learned through practices, demonstration, feedback, and also interpersonal communication.

\section{Digital Learning Material}

Digital learning materials can be defined as the digitized and interconnected learning materials. The digitalization of learning material supports teacher and students' activity to achieve the learning objective of social studies learning (Antoun, Nasr, \& Zgheib, 2015; Dlouhá \& Pospíśilová, 2018). Theoretically, digital learning material can motivate students to learn social studies learning. According to Heafner (2004), students' motivation to use digital learning materials comes from their perspective that the digital learning material can overcome the weakness of printed-out textbooks. Digital learning material helps students to get a deeper understanding of the learning subject because of its ability to gather information faster (Zwart, Van Luit, Noroozi, \& Goei, 2017). By its ability to gather information, digital learning material can give benefits such as time and cost efficiency (Russo, 2019) and unlimited access service (Cheon, Lee, Crooks, \& Song, 2012). Teachers and students also tend to accept the digital learning material as the advancement of learning (Asiry, 2017; Sariyatun, Joebagio, and Akhyar, 2018).

Moreover, many researchers explain that the use of digital online learning material also can lead students to become more autonomous and independent (Edwards and McKinnell, 2007; Warschauer, 2007; Ting, 2015). Ting (2015) explains that the students' autonomy or independence is constructed by their learning experience when they explore and select the information or data provided in the digital learning materials. It means students become active users of the internet and technology in their learning activities. In Mossberger's (2014) perspective, students become a digital learner or digital native who takes interaction and communication in cyberspace. Moreover, according to Brown (2009), online interaction and communication can affect students' identity and social attitudes.

Digital learning materials can construct the students' social skills in different mechanisms than the printed-out textbooks. Students are provided with multiple perspectives about social phenomena in society when they use digital learning material (Ferguson, 2002). According to Elik, Wiener, and Corkum (2010), digital learning material provides sustainable feedback to students when they learn at home or in the classroom. It means, students should establish communication and collaboration with others when using digital learning material (McKnight 2016). Basically, students must have several skills such as negotiation, team working, group decision making, and task management in direct social interactions (Schrage, 1990). Meanwhile, in digital learning, students need more additional skills such as group motivation, collaboration, and confidence (Salmon, 2000). This means that students need social skills in using digital learning material. The digital learning environment stimulates students to participate actively in social activities (Rahimi and Katal, 2012). 
In terms of the correlation between social skill and internet usage, several researches has reported about the problematic internet use (PIU), which can be defined as the negative impact of the internet on human psychological and social interaction. PIU is a negative behavioral and cognitive symptom that can be detrimental for the social, academic, and professional development of an individual (Caplan, 2005). Caplan (2003) reports about the over usage of online social interaction that makes individuals who have a lack of self-presentational skill are likely to choose online social interaction rather than face-toface communication. The internet may be limiting the scope of information to those who hold the same views and it reduces exposure or tolerance to other groups and ideas. However, it must be noted that PIU is mostly derived from internet addiction. According to Davis (2001), PIU relates to abuse and overuse of internet usage for negative necessity.

In the context of education, PIU can be the result of a lack of non-verbal cues in students' online interaction. Non-verbal interaction such as gestures, eye contacts, hesitations, and body languages are hard to be measured during online interaction. Thus, it requires direct interaction and the physical appearance of both teachers and students in the learning process. However, according to Putnam (2000), this issue can be overcome through computer-mediated communication. On the opposite, Mossberger (2010) believes that the internet can be better for fostering social engagement because of the absence of non-verbal or social cues in computer-mediated communication. Mossberger then assumes that it can help to encourage trust among users.

Based on the above theoretical discussion, it can be highlighted that the use of digital learning material can shape students' social skills differently because of the high intensity of online interaction and communication. However, the use of digital learning material can produce two outcomes in social science learning. First, digital learning material can improve the quality of social science learning because of its benefits. It means the use of social science digital learning material can give a better improvement on students' social skills rather than the conventional printed-out textbooks even though the social interaction and communication are held indirectly in cyberspace. Second, digital learning material can shape students' social skills through online interaction and communication. Thus, the use of digital learning can result in a negative or positive impact on the construction of students' social skills.

\section{Research Hypothesis}

Based on the above theoretical framework, it can be summarized that the effect of digital learning material in social studies learning is uncertain. Therefore, the hypothesis proposed in this research is that there is no difference between the score of students' social skills using digital learning material and printed-out learning material.

\section{METHOD}

\section{Research Design}

The design of the research was experimental research. The authors made an experiment to use digital learning material in the social studies learning process and measure its 
effect on the improvement of students' social skills. To measure the effect of digital learning material, the authors made a comparison between the score of students' social skills in the experimental group and the control group.

\section{Research Sites}

The research sites were the Junior High Schools 1 Surakarta and Junior High School 4 Surakarta in Surakarta City, Central Java, Indonesia. The research was conducted in three months from February to April 2019.

\section{Research participants}

The research participants were 80 junior high school students. The students came from the regular classes in two junior high schools. The authors then selected the students based on several criteria such as students are active users of the internet and technology, had no medical or genetic disorder, physical and intellectual disability, or no past psychiatric condition. Besides that, the students' experience in using digital and internet access is also being considered. The characteristics of the subject of research can be seen in table 1:

Table 1

The characteristics of students

\begin{tabular}{llllll}
\hline No & Sex & Total & Percentage (\%) & Internet and Digital Access (\%) \\
\hline 1 & Female & 46 & 59 & 53 & 59 \\
\hline 2 & Male & 34 & 41 & 37 & 41 \\
\hline Total & 80 & 100 & 90 & 100 \\
\hline
\end{tabular}

The students were then grouped into the experimental group and the control group. There were two control groups and two experimental groups. Each group consisted of 20 students. Students in the control group learnt social studies by using printed-out textbooks. Meanwhile, students in the experimental group learnt social studies by using digital learning materials.

\section{Materials and Research Procedure}

To measure the effect of digital learning material, the authors made a comparison between the score of students' social skills in the experimental group and the control group. Students in the control group used a printed-out textbook published by the government. The textbook was composed in a thematic approach consisting of the learning material of social science disciplines such as history, economy, sociology, and geography. Meanwhile, students in the experimental group used digital learning materials. The digital learning material used in this research was developed by Sariyatun, Hermanu Joebagio, Esti Dwi Wardayati, and Andrias Prayitno (2019) entitled Social Studies Learning with Scientific-Thematic Approach. The snapshots of the digital learning material can be seen in figure 1 . 

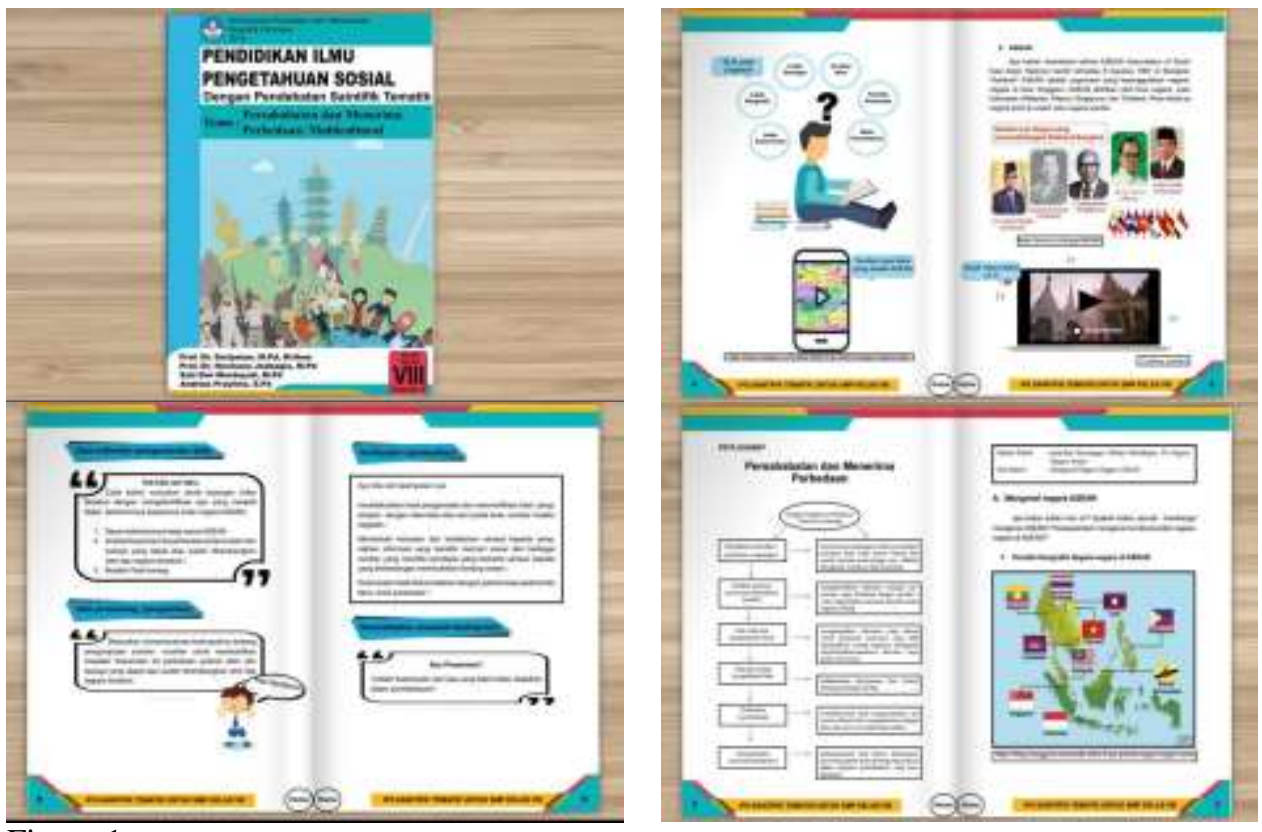

Figure 1

The snapshots of the digital learning material used in the experimental groups

Substantively, the content of the digital learning material was similar with the printedout textbook. Several additional parts represented in the tools to online communication and exploration, especially in the students' task. The digital learning material was connected to the internet and it can be used by students independently in school or their home. The learning process in the control groups and the experimental groups were held in the same learning model. In the experimental group, the authors tried to emphasize on the effect of digitalization and how it gave impact on the construction of social skills.

\section{Research Instrument and Data Collection}

The research instrument was composed based on the framework of the Social Skills Inventory (SSI) developed by Riggio (1986) with some adjustments along with the context of Indonesian education. As reviewed by Matson and Wilkins (2009), there were 48 psychometrics measurements of social skills. However, one of the social skills framework and conceptualization that is mostly used by the researchers is the Social Skills Inventory. SSI consists of six basic abilities of social skills, namely (1) emotional expressivity that relates to the individual ability to manage his attitudes, status, and communication; (2) emotional sensitivity that reflects the decoding skills to caught others' emotions, beliefs, or attitudes; (3) emotional control that relates to a skill to manage non-verbal and emotional expressions; 4) social expressivity that refers to the ability to manage verbal expression, and initiate conversations; 5) social sensitivity that relates to the ability for encoding verbal communication and receipting the social norms; 
and 6) social control that refers to the ability for managing social self-displays, socially adept, and self-confident. Besides that, additional social skills were added to the research instrument such as the aspect of communication, cooperation, empathy, and solidarity.

The items of research question were composed of 61 Likert-type rating scale items, ranging from 1 (Strongly not Agree) to 5 (Strongly Agree). Based on the value of Cronbach's alpha, the items of research questions were reliable with the range of values from 0.700 to 0.850 . The validity of the instrument was measured by the Pearson product-moment correlations ranging from 0.216 to 0.833 or higher than $\mathrm{r}_{\text {table }}(.361)$. The detailed instrument validity can be seen in table 2 :

Table 2

Variable scale intercorrelations

\begin{tabular}{lllllllllll}
\hline & EE & ES & EC & SE & SS & SC & S \& E & Com & Coo & SSI \\
\hline EE & & $.470^{* * *}$ & .135 & $.394^{*}$ & -.163 & .251 & .230 & $.578^{* *}$ & .255 & .556 \\
\hline ES & $.470^{* * *}$ & & $.591^{* *}$ & $.608^{* *}$ & .030 & .320 & $.460^{*}$ & $.619^{* *}$ & $.552^{* * *}$ & .833 \\
\hline EC & .135 & $.591^{* * *}$ & & .346 & -.040 & $.472^{* * *}$ & .300 & $.484^{* *}$ & $.709^{* *}$ & .658 \\
\hline SE & $.394^{* *}$ & $.608^{* * *}$ & .346 & & .229 & .334 & $.437^{*}$ & $.457^{*}$ & .247 & .695 \\
\hline SS & -.163 & .030 & -.040 & .229 & & .057 & .073 & -.037 & .039 & .216 \\
\hline SC & .251 & .320 & $.472^{* * *}$ & .334 & .057 & & $.406^{*}$ & $.434^{*}$ & $.431^{*}$ & .638 \\
\hline S \& E & .230 & $.460^{* *}$ & .300 & $.437^{* *}$ & .073 & $.406^{*}$ & & .134 & .253 & .562 \\
\hline Com & $.578^{* * *}$ & $.619^{* * *}$ & $.484^{* *}$ & $.457^{* *}$ & -.037 & $.434^{* *}$ & .134 & & $.470^{* *}$ & .755 \\
\hline Coo & .255 & $.552^{* * *}$ & $.709^{* *}$ & .247 & .039 & $.431^{*}$ & .253 & $.470^{* *}$ & & $.673^{* * *}$ \\
\hline SSI & $.556^{* * *}$ & $.833^{* * *}$ & $.658^{* *}$ & $.695^{* *}$ & .216 & $.638^{* *}$ & $.562^{* *}$ & $.755^{* *}$ & $.673^{* *}$ & \\
\hline
\end{tabular}

Besides the questionnaires, for the research purposes, the social science teacher was involved in the study as the observer to report students' behaviour based on the instrument scales. The teachers' observation was conducted for three months. To strengthen the level of objectivity, each observer had been given similar instruction and preparation.

\section{Data Analysis}

The data had been analysed using Statistical Package for the Social Sciences (SPSS) Version $20^{\text {th }}$. The statistical calculation method depends on statistical parametric and equalization of the data. The normality and homogeneity of variance were calculated using SPSS to determine the appropriate statistical approach for analysing the data.

\section{FINDINGS}

\section{The Normality and Homogeneity Tests}

The result of data normality and homogeneity tests could be seen in table 3 : 
Table 3

Normality data test

\begin{tabular}{llll}
\hline \multirow{2}{*}{ SSI } & Group & Lilliefors & Shapiro-Wilk \\
\cline { 2 - 4 } & Sig. & Sig. \\
\cline { 2 - 4 } & Experimental & .200 & .243 \\
\hline & Control & .200 & .662 \\
\hline
\end{tabular}

The value of Liliefors both in the control group and experimental group were 0.200 . The value of the Lilliefors showed that the p-value of SSI was greater than the significance level (0.05). These mean that the distribution of data spread normally on the control group and experimental group.

Table 4

The Data Homogeneity Variance

\begin{tabular}{llllll}
\hline & Levene Statistic & & df1 & df2 & Sig. \\
\cline { 2 - 6 } SSI & Calculated on Mean & 3.292 & 1 & 78 & .075 \\
\cline { 2 - 6 } & Calculated on Median & 2.358 & 1 & 78 & .130 \\
\cline { 2 - 6 } & Calculated on Median with adjusted $d f$ & 2.358 & 1 & 56.935 & .130 \\
\cline { 2 - 6 } & Calculated on Trimmed Mean & 2.261 & 1 & 78 & .076 \\
\hline
\end{tabular}

Based on the Levene Statistic Test (Table 4), it could be highlighted that the data of the control group and the experimental group were homogeny. It could be proved based on Mean Sig. 0.075, which was greater than 0.05. It means the data variance was homogeny. The result of the data normality and data homogeneity showed that the data were possible to be compared on the parametric independent t-test.

\section{The Result of Parametric Independent Sample T-Test}

The result of the parametric independent sample t-test showed the statistical difference between the control groups and the experimental groups.

Table 5

$\underline{\text { Independent t-test result }}$

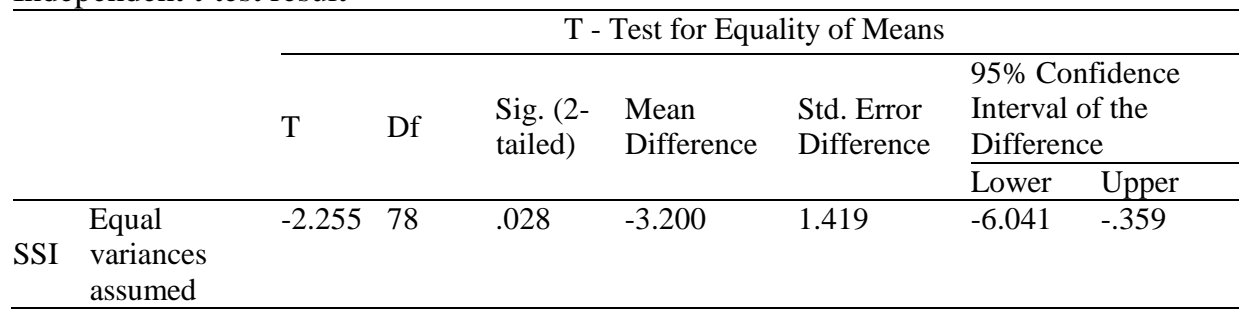

Table 5 showed that the value of the sig 2-tailed Social Skills Inventory (SSI) was 0.028 or below the significance level $(5 \%)$. Based on the result, it could be stated that there was a significant difference between the experimental groups and control groups. It means that students in the experimental group, which use digital learning materials, had higher scores of social skills than the students in the control group, which use the printed-out textbook. 


\section{DISCUSSION}

The result of the research shows the difference between the use of the printed-out textbook and the use of digital learning material in social studies learning. The results of research also proves that the use of digital learning material affects the improvement of students' social skills. This is in line with Antoun, Nasr, \& Zgheib (2015) and Dlouhá \& Pospíśilová (2018) research findings of the role of digital learning material in helping teachers and students to achieve the objectives of social studies learning. Moreover, the improvement of students' social skills in the experimental group confirms Heafner (2004), Asiry (2017), and Sariyatun, Joebagio, and Akhyar (2018) research about the positive impact of digital learning material in social studies learning. It can be pointed out that the use of digital learning gives a contribution to the practices of social studies learning, especially in improving students' social skills.

The improvement of social skills also confirms the role of digital learning material in providing connectivity among students that become the determinant factor to promote social interaction and communication. The connectivity of the digital learning material has made it easy for students in sharing and learning with teachers and classmates outside of the classroom. As stated by McKnight (2016), digital learning material can stimulate students to actively explore information and share their knowledge with others. The use of digital learning material supports interactive communication for teachers and students to discuss their projects or lessons. Through digital learning material, students can be fluent in using technology and connecting with others in searching information or data. It means that the use of digital learning has enabled students' opportunities to expand their interaction with teachers and classmates in a digital environment.

From Schrage's (1990) perspective, interaction and communication in online collaborative learning require some additional skills such as negotiation, team working, group decision making, and task management. Moreover, Salmon (2000) added several factors in online collaboration such as motivation, group dynamics, and growing confidence. It means that technology can provide online collaborative learning and also a virtual trip to students. The use of digital learning material can build social interaction among students and promote learning in a consistent partnership with the studentoriented approach. It means the presence of technology and connectivity through social science digital learning material help to boost their social ability. As stated by Rahimi and Katal (2012), the digital learning environment stimulates students to participate actively in social activities, such as in the form of sustainable feedback. Along with Elik, Wiener, and Corkum's (2010) argumentation, digital learning material provides sustainable feedback to students when they learn at home or in the classroom. At this point, the authors perceive that this interactive process creates a social-cyberspace environment where the students can hold social interaction and communication and maintain their social skills through online collaborative learning.

The results of the research have not given any evidence of Problematic Internet Use (PIU). Although online-digital interaction and communication can result in a lack of non-verbal clues such as gestures, eye contacts, hesitations, and body language, this research shows that students had built nonverbal communication. This is in line with 
Mossberger (2010) who states that the absence of non-verbal or social cues in computermediated communication helps to encourage trust among the users. The digital learning material can create online social interaction, besides students' autonomy and independence (Edwards and McKinnell, 2007; Warschauer, 2007; Ting, 2015). Brown (2009) has pointed out that online interaction and communication can affect students' identity and other social aspects of students.

The effective socialization between teachers and students in mediated communication using digital learning material must be reciprocal with communication in daily life. In this context, Plaskoff (2015) has suggested three concepts that can be enhanced to foster communication in society and communities namely believing, behaving, and belonging. Believing refers to the idea that the intrinsic value of the community needs to be believed by the members of society. The sense and tendency of members to follow the norms and rules of the community refer to behaving. Moreover, belonging is the sense of the member to share empathy, and solidarity within the community. In the context of this research, affection, trust, solidarity, and other positive relations during social interaction in the classroom activity will affect the health of mediated communication in the online learning environment. Even though the usage of digital learning material has led to the high-intensity of socialization between teachers and students, it still depends on how positive the relationship between them in the classroom.

From the above discussion, the authors believe that the use of digital learning should be implemented in a blended learning approach to improve the effects on students' social skills. The blended learning approach can be implemented in the classroom by combining a conventional learning material and digital learning material. In this context, Lave and Wenger (1991) had introduced the term community of practice. This term can be defined as informal collaborative learning which occurs outside of classrooms. In line with this term, Wenger (2001) argued that a group of people who engaged or interacted in collective learning activities such as the tribe learning to survive, engineers working on a similar project, pupils defining their identity in the school, are several examples of a community of practice. There are some cases of successful online communities that help and boost social skills and social identity of the participants in the community (Gray, 2004). The research conducted by Hara (2009) described a successful online community that possessed the characteristics of Face to Face interaction. In line with it, Niemi (2014) argued that learners in the digital era are content producers as well as users. Thus, the digital media competency consists of social and symbolic mediators through the various digital environments. Consequently, students have to adapt to the rules and norms that have been established by the previous member of the community.

Another result from blended learning is the occurrence of cyberspace learning environments. The cyberspace learning environment has been naturally established as the result of the use of digital learning material where students transmitted the knowledge, social relationship, and interaction with teachers and classmates outside the conventional place-based classroom. In Bates' (2015) perspective, the cyberspace learning environment can be in the form of Online Collaborative Learning (OCL) that is implemented based on Computer-Mediated Communication (CMC). According to 
Harasim (2012), OCL is a kind of learning method in which students use the internet as a medium to collaborate and work together completing their collective task. Thus, OLC and $\mathrm{CMC}$ can be used to connect teachers and students in the cyberspace learning environment.

Based on the above discussion, it can be highlighted that the use of digital learning material improves students' social skills better than the printed-out text-book. Digital learning material has provided a space for students to interact with the teacher and classmates. The use of digital learning material can create a cyberspace learning environment where students can learn about social interaction and communication with their teachers and classmates. This becomes important in dealing with the question about the ability of digital learning material in shaping social skills that theoretically need interpersonal communication and interaction. Moreover, the authors believe that digital learning material can be more useful in the frameworks of collaborative learning and blended learning. However, digital learning material cannot fully replace direct communication or real-world interaction. In the education field, face-to-face interaction is important to teach values and affection to students that cannot be replaced by machines or technology. Overall, this research had proven the effectiveness of the use of digital learning material in improving students' social skills. Furthermore, this research did not examine the characteristic of social skills generated from the use of digital learning material. Therefore, a deep analysis of students' characteristics of social skills should be examined in further research to draw detailed information about students' personal and social identity produced by the use of digital learning material.

\section{CONCLUSION}

This research aims to examine the effect of digital learning material in students' social skills. The result of the research shows that the use of digital learning material improves students' social skills better than the printed-out textbooks. It was proved by the result of statistical analysis that shows the effect of digital learning material in the experimental groups. The improvement of social skills through the use of digital learning material proves its ability to provide connectivity among students that promote social interaction and communication in cyberspace. In this research, the authors did not find a Problematic Internet Use (PIU) in digital learning material utilization. This research shows that students can construct their social skills through online collaborative learning. The limitation of the research lies in its ability to explain more deeply about the detailed explanation of students' social skills generated from the use of digital learning material. Therefore, the authors suggest further research tackles this topic. Beyond this limitation, the authors recommend teachers use digital learning material with a blended learning approach in social studies learning. The use of digital learning with blended learning can maximize the effect of digital learning material and diminishes the potency of PIU.

\section{ACKNOWLEDGMENT}

The authors express deepest gratitude to the Ministry of Research, Technology, and the Higher Education Republic of Indonesia for assistance and funding this research. 


\section{REFERENCES}

Acker, F. van, Van Buuren, H., Kreijns, K., \& Vermeulen, M. (2013). Why teachers use digital learning materials: the role of self-efficacy, subjective norm and attitude. Education and Information Technologies, 18(3), 495-514.

Antoun, J., Nasr, R., \& Zgheib, N. K. (2015). Use of technology in the readiness assurance process of Team Based Learning: paper, Automated Response System, or Computer Based Testing. Computers in Human Behavior, 46(6), 38-44. https://doi.org/10.1016/j.chb.2015.01.003

Asiry, M. A. (2017). Dental students' perceptions of an online learning. Saudi Dental Journal, 29(4), 167 - 170. https://doi.org/10.1016/j.sdentj.2017.03.005

Batra, P. (Ed.). (2008). Social science learning in schools: perspective and challenges. SAGE Publications India.

Brown, J. S. (2009). Growing up: digital: how the web changes work, education, and the ways people learn. Change: The Magazine of Higher Learning, 32(2), 11-20. https://doi.org/10.1080/00091380009601719

Caplan, S. E. (2003). Preference for online social interaction: a theory of problematic internet use and psychosocial well-being. Communication Research, 30(6), 625-648. https://doi.org/10.1177/0093650203257842

Caplan, S. E. (2005). A social skill account of problematic internet use. Journal of Communication, 55(4), 721 - 736. https://doi.org/10.1093/joc/55.4.721

Cheon, J., Lee, S., Crooks, S. M., \& Song, J. (2012). An investigation of mobile learning readiness in higher education based on the theory of planned behavior. $\begin{array}{llll}\text { Computers and } & \text { Education, }\end{array}$ https://doi.org/10.1016/j.compedu.2012.04.015

Chou, W. J., Huang, M. F., Chang, Y. P., Chen, Y. M., Hu, H. F., \& Yen, C. F. (2017). Social skills deficits and their association with internet addiction and activities in adolescents with attention-deficit/hyperactivity disorder. Journal of Behavioral Addictions, 6(1), 42-50. https://doi.org/10.1556/2006.6.2017.005

Davis, R. A. (2001). Cognitive-behavioral model of pathological internet use. Computers in Human Behavior, 17(2), 187-195. https://doi.org/10.1016/S07475632(00)00041-8

Dlouhá, J., \& Pospíšilová, M. (2018). Education for sustainable development goals in public debate: the importance of participatory research in reflecting and supporting the consultation process in developing a vision for czech education. Journal of Cleaner Production, 172(1), 4314-4327. https://doi.org/10.1016/j.jclepro.2017.06.145

Edwards, A., \& McKinnell, S. (2007). Moving from dependence to independence: the 
application of e-learning in higher education. Learning, teaching and assessing in higher education: Developing reflective practice, 68.

Elik, N., Wiener, J., \& Corkum, P. (2010). Pre-service teachers' open-minded thinking dispositions, readiness to learn, and attitudes about learning and behavioural difficulties in students. European Journal of Teacher Education, 33(2), 127-146. https://doi.org/10.1080/02619760903524658

Elliott, S., Malecki, C., \& Demaray, M. (2004). New directions in social skills assessment and intervention for elementary and middle school students. Exceptionality, 9(2), 19-32. https://doi.org/10.1207/s15327035ex091\&2_3

Ferguson, J., Fowler, J., Hanley, M., \& Schafer, J. (2002). Building a digital library in support of distance learning. Journal of Library Administration, 37(3), 317-331. https://doi.org/10.1300/J111v37n03_26

Fligstein, N. (2001). Social skill and the theory of fields. Sociological Theory, 19(2), 105 - 125. https://doi.org/10.1111/0735-2751.00132

García-Álvarez, M. T., Novo-Corti, I., \& Varela-Candamio, L. (2018). The effects of social networks on the assessment of virtual learning environments: a study for social sciences degrees. Telematics and Informatics, 35(4), 1005-1017.

Gresham, F. M., \& Elliott, S. N. (1984). Assessment and classification of children's social skills: a review of methods and issues. School Psychology Review, 13(3), 292301.

Gresham, F. M., Elliott, S. N., \& Kettler, R. J. (2010). Base rates of social skills acquisition/performance deficits, strengths, and problem behaviors: an analysis of the social skills improvement system-rating scales. Psychological Assessment, 22(4), 809815. https://doi.org/10.1037/a0020255

Hara, N. (2009). Chapter 2: theoretical foundations in communities of practice: fostering peer-to-peer learning and informal knowledge sharing in the work place. discourse \& society. Berlin, German: Springer.

Harasim, L. (2012). Learning theory and online technologies. Learning theory and online technologies. New York: Routledge. https://doi.org/10.4324/9780203846933

Heafner, T. (2004). Using technology to motivate students to learn social studies. Contemporary Issues in Technology and Teacher Education, 4(1), 42-53.

Hutching, S. (2019). The social skills handbook: practical activities for social communication. Routledge.

Johnson, D. W., \& Johnson, R. T. (1989). Cooperation and competition: theory and research. US: Interaction Book Company. 
Kaviani, K. (2006). Influences on social studies teachers' issue-selection for classroom discussion: social positioning and media. Social Studies Research and Practice, 1(2), 201-222.

Legare, C. H., Opfer, J. E., Busch, J. T. A., \& Shtulman, A. (2018). A field guide for teaching evolution in the social sciences. Evolution and Human Behavior, 39(3), 257268. https://doi.org/10.1016/j.evolhumbehav.2018.01.002

Matson, J. L., \& Wilkins, J. (2009). Psychometric testing methods for children's social skills. Research in Developmental Disabilities, 30(2), 249-274. https://doi.org/10.1016/j.ridd.2008.04.002

McKnight, K., O’Malley, K., Ruzic, R., Horsley, M., Franey, J. J., \& Bassett, K. (2016). Teaching in a digital age: how educators use technology to improve student learning. Journal of Research on Technology in Education, 48(3), 194-211. https://doi.org/10.1080/15391523.2016.1175856

Mossberger, K. (2010). Toward digital citizenship: addressing inequality in the information age. In Chadwick, A. (Ed.), Howard, P. (Ed.). Routledge handbook of internet politics. London: Routledge, https://doi.org/10.4324/9780203962541

Mossberger, K. (2014). Digital citizenship: broadband, mobile use, and activities online. International Political Science Association Conference, Montreal.

Niemi, H., Harju, V., Vivitsou, M., Viitanen, K., Multisilta, J., \& Kuokkanen, A. (2014). Digital storytelling for $21^{\text {st }}$ century skills in virtual learning environments. Creative Education, 5(9), 657-671. https://doi.org/10.4236/ce.2014.59078

Plaskoff, J. (2015). Intersubjectivity and community-building: learning to learn organizationally. In Handbook of organizational learning and knowledge management. John Wiley \& Sons. https://doi.org/10.1002/9781119207245.ch10

Putnam, R. D. (2000). Bowling alone: the collapse and revival of american community. New York: Simon und Schuster. https://doi.org/10.2307/3089235

Rahimi, M., \& Katal, M. (2012). The role of metacognitive listening strategies awareness and podcast-use readiness in using podcasting for learning english as a foreign language. Computers in Human Behavior, 28(4), 1153-1161. https://doi.org/10.1016/j.chb.2012.01.025

Riggio, R. E. (1986). Assessment of basic social skills. Journal of Personality and Social Psychology, 51(3), 649-660. https://doi.org/10.1037/0022-3514.51.3.649

Riggio, R. E., \& Reichard, R. J. (2008). The emotional and social intelligences of effective leadership: an emotional and social skill approach. Journal of Managerial Psychology, 23(2), 169-185. https://doi.org/10.1108/02683940810850808

Russo, J. M., Williford, A. P., Markowitz, A. J., Vitiello, V. E., \& Bassok, D. (2019). 
Examining the validity of a widely-used school readiness assessment: implications for teachers and early childhood programs. Early Childhood Research Quarterly. https://doi.org/10.1016/j.ecresq.2019.02.003

Saglam, H. I. (2011). An investigation on teaching materials used in social studies lesson. Turkish Online Journal of Educational Technology-TOJET, 10(1), 36-44.

Sariyatun, S., Joebagio, Hermanu., \& Akhyar, Muhammad. (2018). Teachers' perception on digital teaching material development in social science education. Journal of Turkish Science Education, 15(1), 13-21.

Singer, A. J. (2008). Social studies for secondary schools: Teaching to learn, learning to teach. London: Routledge.

Thorndike, R. L., \& Stein, S. (1937). An Evaluation of The Attempts to Measure Social Intelligence. Psychological Bulletin, 34(5), 275-285. https://doi.org/10.1037/h0053850

Ting, Y. L. (2015). Tapping into students' digital literacy and designing negotiated learning to promote learner autonomy. The Internet and Higher Education, 26, 25-32.

Warschauer, M. (2007). The paradoxical future of digital learning. Learning Inquiry, 1(1), 41-49.

Wenger, E. (2001). Supporting communities of practice: a survey of communityoriented technologies. retrieved from: https://pdfs.semanticscholar.org/066c/aaa4903b82a97bcbe574e1455f811ae549f9.pdf

Zulkifli. (2019). Disparity among Indonesian sociology of education textbooks. Journal of Educational Media, Memory, and Society, 11(2), 86-104. Retrieved May 6, 2020, from https://www.berghahnjournals.com/view/journals/jemms/11/2/jemms110205.xml

Zwart, D. P., Van Luit, J. E., Noroozi, O., \& Goei, S. L. (2017). The effects of digital learning material on students' mathematics learning in vocational education. Cogent Education, 4(1), 1313581. 